\title{
ANALISA KANDUNGAN KIMIA DAN PEMANFAATAN BAWANG TIWAI ( ELEUTHERINE AMERICANA MERR) UNTUK BAHAN BAKU INDUSTRI
}

\author{
Oleh : \\ Suroto $\mathrm{HS}^{11}$ \\ Eldha Sampepana ${ }^{21}$
}

\begin{abstract}
This research aims to get information about the utilization of chemical compound contained in Bawang Tiwai. Bawang Tiwai collected from forest and merchandizer were sorted according to their age/rotten/dries and defects. The next step is making specimens simplisia by using knifes or slicer, after that they are dried naturally by the sun for about 2 weeks and finally they are powdered by using blender. Extraction is done by solving the sample in methanol and hot water solution. The mixing is then shaked thoroughly by a shaker for 24 hours or overnight. Based on chemical analysis, Bawang Tiwai contains chemical compounds like tanin, fenol, carbohydrate, and protein. Bawang Tiwai can be made as a raw material of pharmaeutical and food additive industries.
\end{abstract}

Key words : bawang tiwai, extraction, chemical compound, industry

\section{PENDAHULUAN}

$\mathrm{M}$

asyarakat di sekitar kawasan hutan memiliki pengetahuan lokal dalam pemanfaatan tumbuhan/bahan alami untuk percobaan. Pengetahuan dan pengalaman tradisional dari penduduk tersebut merupakan informasi yang penting mengenai jenis dan manfaat tumbuhan sebagai bahan pengobatan tradisional dan untuk pengembangan pemanfaatan yang lain. Kemajuan ilmu pengetahuan dan teknologi dapat menyingkap faktor-faktor yang menjadi kebiasaan masyarakat yang telah diwariskan secara turun temurun dengan melakukan penelitian sehingga akan diperoleh data yang akurat berdasarkan riset.

Kawasan Indonesia memiliki keanekaragaman hayati yang melimpah berupa tumbuhtumbuhan diantaranya terdapat tumbuhan obat, sehingga indonesia menjadi negara terbesar kedua didunia yang memiliki tumbuhan obat setelah Brazilia (Anonim, 2004) kawasan dua negara ini dihuni sekitar 370 juta suku asli yang memiliki kekayaan iptek pengobatan tradisional (Sudiarto dan Monorahardjo dalam Sukrasno, 2002). Ratusan jenis tanaman obat Indonesia telah digunakan sebagai obat tradisional, salah satu diantaranya adalah Bawang Tiwai/Bawang Dayak (Eleutherine americana MERR) yang telah dimanfaatkan masyarakat suku Dayak di pulau Kalimantan secara turun temurun sebagai obat kista, tumor atau kanker untuk itu perlu dilakukan penelitian dengan tujuan memperoleh informasi kandungan kimia dan manfaat senyawa kimia yang terdapat pada bawang tiwai lebih lengkap.

\section{BAHAN DAN METODA}

Penelitian dilaksanakan di Laboratorium Balai Riset dan Standardisasi Industri Samarinda, dan di Laboratorium Kimia Kayu Fakultas Kehutanan Universitas Mulawarman Samarinda. Alat 
yang digunakan antara lain tabung reaksi, blender, alat ekstraksi (soxlet), cawan penguat, rotary vakun i evaporator, gelas piala, pipet volumetrik, oven, desikator, neraca analitik, erlenmyer, pipet tetes, statif, cotong, pemisah, spray, shacker, pisau, sliser, Hot plat, loup, reflux, spectrofotometer, destilasi unit, buret, botol ekstraksi, tanur, dan degester.

Bahan yang digunakan antara lain bubuk dan simplesia bawang tiwai, methanol, khloroform, n-heksana, buthanol, alkohol, asam klorida, serbuk magnisium, asam sulfat, asam acetat anhidrid, pereaksi molish, 2-4-dinitrofenil hidrazin, reagen dragendorf, kalium iodida, formaldehid, 1.1-diphynil-2 picrylhidrazyl (DPPM), natrium hidroksida, kjeldhal katalisator, indikator phenolftalein, metil merah, natrium thiosulfat, indikator kanji, indikator $\mathrm{Pb}$, tembaga sulfat, natrium karbonat, asam citrat, fenol, indikator metil jingga, kalium dichromat, ammonium hidroksida, penyangga fosfat. Dalam penelitian ini metode yang digunakan adalah:

\section{Persiapan sampel}

Bawang tiwai yang diperoleh dari hutan atau dari pedagang dilakukan penyortiran dan pembersihan antara lain daun, akar, yang tersisa dan kulit yang sudah tua/busuk/kering/cacat. Kemudian bawang tiwai dicuci dengan air bersih (ledeng) untuk menghilangkan kotoran yang menempel/tersisa pada kulit, setelah itu ditiriskan dan dikeringkan dengan cara diangin-anginkan.

Tahap berikutnya bawang tiwai dibuat simplisia dengan pisau atau dengan sliser, kemudian dikeringkan dengan sinar matahari selama 2 minggu. Uji kering simplisia dengan cara mengambil simplisia secara acak, selanjutnya sampel yang terambil dipatahkan dengan jari tangan, bila simplisia dapat dipatahkan dengan mudah maka diduga simplisia sudah kering. Tahap berikutnya pembuatan contoh uji yaitu dalam bentuk simplisia dan bubuk bawang tiwai. Khusus untuk bubuk bawang tiwai dengan 40-60 mesh dibuat dengan blender. Adapun tahapan tersebut dapat dilihat pada Gambar 1.

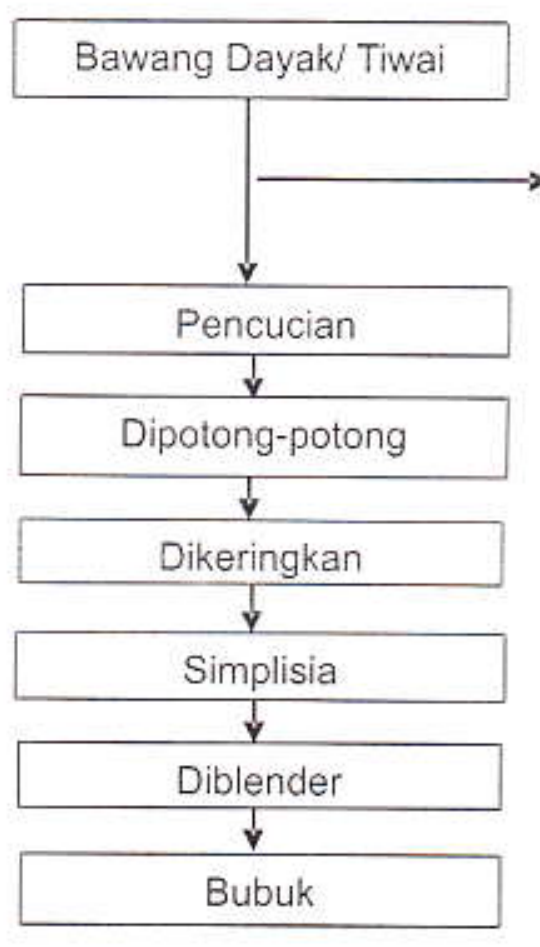

Dibersihkan : Batang dan daun, Akar dan Kulit yang tua/ rusak

Gambar 1. Diagram Pembuatan Sampel Bawang Tiwai 


\section{Pengujian (ekstraksi)}

Pada Gambar 2 adalah tahapan pengujian ekstrak bawang tiwai. Ekstraksi dilakukan dengan cara melarutkan sampel didalam larutan methanol dan air panas, kemudian dikocok secara berkelanjutan dengan menggunakan sacker selama \pm 24 jam (overnight). Adapun tahapan ekstraksi pada Gambar 2.

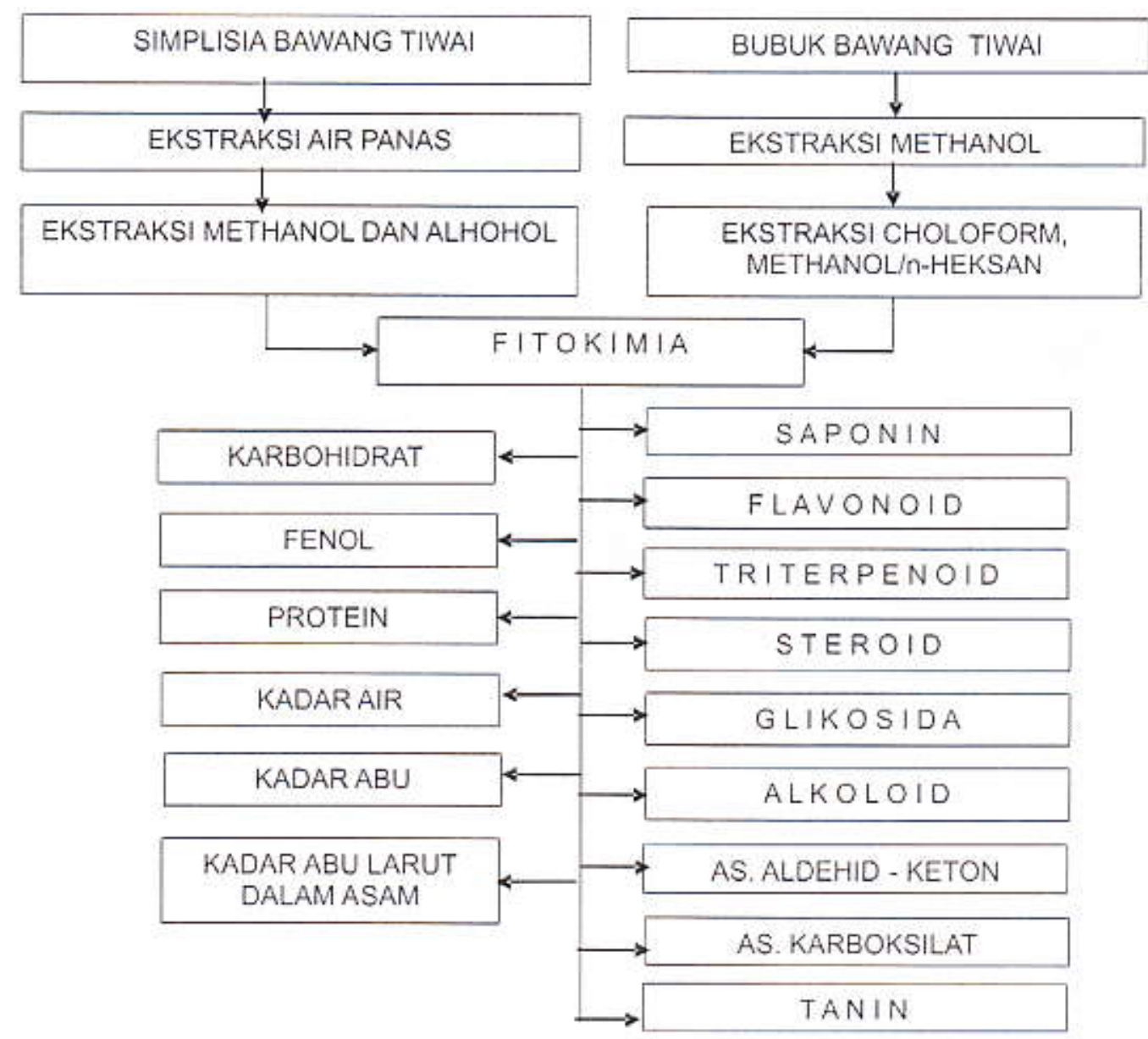

Gambar 2. Tahapan Pengujian Ekstrak Bawang Tiwai (Eleutherine americana Merr)

\section{Ekstraksi}

\section{Ekstraksi Metanol}

Sampel $(2 \times 100 \mathrm{~g})$ direndam dengan metanol (masing-masing $3 \times 500 \mathrm{ml}$ ) selama 24 jam dengan dibantu pengocokan (shaking). Selanjutnya larutan ekstrak disaring dengan menggunakan kertas saring untuk kemudian dipekatkan dengan rotary evaporator. Pengeringan ekstrak selanjutnya dilakukan dengan pengeringan vakum untuk memperoleh padatan ekstrak methanol. Kuantifikasi ekstrak dihitung berdasarkan berat sampel kering udara.

\section{Ekstraksi Air Panas}

Sampel ( $50 \mathrm{~g}$ ) direndam dengan $200 \mathrm{ml}$ air panas dan dipanaskan selama 1 jam pada pelat pemanas (hot plate). Selanjutnya larutan ekstrak disaring dengan menggunakan kertas saring untuk kemudian dipekatkan pada rotary evaporator. Pengeringan untuk memperoleh padatan dilakukan dengan bantuan pengering vakum (vacuum dryer). Kuantifikasi ekstrak dihitung berdasarkan berat sampel kering udara. 


\section{Analisis KLT/TLC}

Analisis kromatografi lapis tipis atau thin-layer chromatography dilakukan pada pelat silika gel $60 \mathrm{~F}_{254}$. Ekstrak yang dilarutkan dalam pelarut yang sesuai (metanol, etanol, aseton, kloroform atau pelarut lain) diteteskan pada pelat KLT dengan pipet kapiler. Pelat selanjutnya dikembangkan dengan pelarut-pelarut pada sistem normal-phase. Karakteristik penyerapan sinar ultraviolet dideteksi pada panjang gelombang 254 dan $365 \mathrm{~nm}$.

\section{Analisis Fitokimia}

\section{Saponin}

Pengujian dilakukan dengan memasukkan sebanyak panas ke dalam ekstrak, selanjutnya larutan didinginkan dan dikocok selama 10 detik. Terbentuknya buih mantap selama kurang lebih 10 menit dengan ketinggian $1 \mathrm{~cm}$ sampai $10 \mathrm{~cm}$ dan tidak hilang bila ditambahkan $\mathrm{HCl} 2 \mathrm{~N}$ menandakan bahwa ekstrak yang diuji mengandung saponin.

\section{Flavonoid}

Serbuk magnesium dan asam klorida dimasukkan ke dalam ekstrak yang dilarutkan dalam etanol. Reaksi yang terjadi diikuti dengan perubahan warna pada larutan, apabila terbentuk warna kuning hingga cokelat maka contoh uji dinyatakan positif mengandung flavonoid.

\section{Glikosida -karbohidrat}

Identifikasi adanya kandungan glikosida - karbohidrat dilakukan dengan menggunakan pereaksi Molisch. Pereaksi Molisch diteteskan ke dalam ekstrak kemudian larutan dikocok, selanjutnya melalui dinding tabung ditambahkan sedikit asam sulfat pekat. Kehadiran glikosida karbohidrat ditandai dengan terbentuknya cincin ungu di antara 2 lapisan.

\section{Aldehida-keton}

Ekstrak yang telah dikembangkan pada plat KLT, disemprot dengan larutan 2,4-dinitrofenil hidrazin dalam $100 \mathrm{ml} \mathrm{HCl} 2 \mathrm{~N}$ dan etanol. Aldehida dan keton akan menghasilkan warna kuning merah setelah dilakukan penyemprotan dengan larutan tersebut.

\section{Tanin}

\section{Metode charring}

Serbuk diekstrak dengan $\mathrm{HCl} 2 \mathrm{M}$ dengan pemanasan selama 30 menit. Tanin akan menunjukkan warna merah setelah penambahan pengembang forestal $(\mathrm{AcOH}-\mathrm{H} 20-\mathrm{HCl} 30: 10: 3)$. Selanjutnya campuran ekstrak dan pengembang forestal diekstrak dengan butil alkohol. Lapisan butil alkohol dipipet dan dikeringkan untuk selanjutnya diperiksa pada pelat TLC dengan pengembang forestal. Tanin terkondensasi menunjukkan serapan kuat pada 254 dan $365 \mathrm{~nm}$ dengan karakteristik biru fluoresensi.

\section{Metode Stiasny number}

$50 \mathrm{ml}$ ekstrak air dimasukkan dalam labu pendidih dan ditambahkan dengan $10 \mathrm{ml}$ larutan formaldehida $37 \%$ dan $5 \mathrm{ml} \mathrm{HCl}$ pekat. Campuran dididihkan secara reflux selama 30 menit. Hasil ekstraksi disaring dengan gelas filter (crucible filter) dan hasil endapan dikeringkan dalam oven dan ditimbang. Bilangan stiasny dinyatakan sebagai perbandingan antara berat kering tanur endapan terhadap berat ekstrak total. Semakin tinggi nilai bilangan stiasny menunjukkan kecenderungan kelarutan tanin yang baik. 


\section{Penetapan Kadar Fenol}

Optimalkan alat spektrofotometer sesuai dengan petunjuk penggunaan alat untuk pengujian fenol kadar rendah, ukur $500 \mathrm{ml}$ ekstrak bawang tiwai dan masukkan ke dalam gelas piala $1000 \mathrm{ml}$, tambahkan $12 \mathrm{ml}$ larutan $\mathrm{NH}, \mathrm{OH} 0,5 \mathrm{~N}$ dan atur $\mathrm{pH}$ menjadi $7,9 \pm 0,1$ dengan penambahan larutan penyangga fosfat, larutan tersebut dimasukkan ke dalam corong pemisah kemudian tambahkan $3,0 \mathrm{ml}$ larutan aminoantipirin lalu diaduk. Tambahkan 3,0 ml larutan kalium ferisianida sambil diaduk, diamkan selama 3 menit sampai timbul warna kuning jernih. Ekstraksi dengan 25 mi kloroform dan kocok corong pemisah paling sedikit 10 kali, diamkan sampai lapisan kloroform terpisah. Keluarkan lapisan kloroform melalui kertas saring yang telah dilapisi dengan $5 \mathrm{gr}$ natrium sulfat bebas air, lalu masukan ke dalam kuvet pada alat spektrofotometer pada panjang gelombang $460 \mathrm{~nm}$. Apabila perbedaan hasil pengukuran secara duplo lebih besar dari $2 \%$, periksa keadaan alat dan ulangi pekerjaan mulai dari awal, dan apabila lebih kecil atau sama dengan rata-ratakan hasilnya. Buat kurva kalibrasi dari data diatas atau tentukan persamaan garis lurusnya.

\section{Hasil Pengujian Ekstraksi}

Berdasarkan daya kelarutan bawang tiwai (Eleutherine americana Merr) dari pelarut organik maupun dengan pelarut air panas menghasilkan padatan coklat pekat dan coklat marum (gummy). non kristalen dan non aromatik dimana persen kelarutan methanol lebih besar dibandingkan dengan air panas. Perbedaan kelarutan dan jumlah persen hasil ekstraksi bawang tiwai diduga bahwa kandungan senyawa yang terdapat pada bawang tiwai lebih mudah larut dalam pelarut organik sehingga persen yang diperoleh lebih besar. Hal ini diperjelas oleh Sukrasno dkk (2006) bahwa kandungan senyawa kimia yang terdapat pada bawang tiwai termasuk senyawa polar yang mudah larut dalam pelarut polar seperti etanol, metanol, air atau campuran.

\section{Hasil Analisa KLC/TLC}

Berdasarkan hasil analisa ekstrak bawang tiwai dengan menggunakan methanol dan dianalisa dengan kromatografi dan diteruskan ke karakteristik penyerapan sinar ultraviolet dideteksi pada panjang gelombang $254 \mathrm{~nm}$ - $365 \mathrm{~nm}$ didominasi oleh spot kuning dengan senyawa fluorensi biru-hijau hingga merah, hasil analisa ini dapat dilihat pada Gambar 4. Sedangkan ekstrak air panas didominasi oleh spot-spot dengan serapan kuat dengan flourensi biru-hijau pada panjang gelombang $354 \mathrm{~nm}-365 \mathrm{~nm}$, hal ini dapat dilihat pada Gambar 5 .

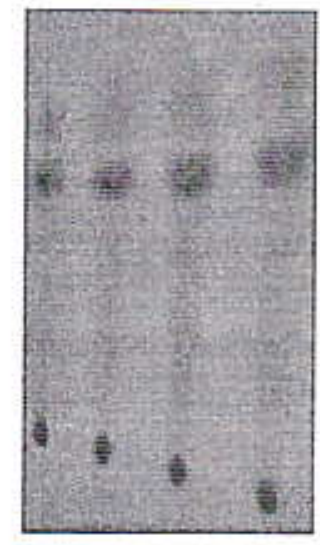

$254 \mathrm{~nm}$

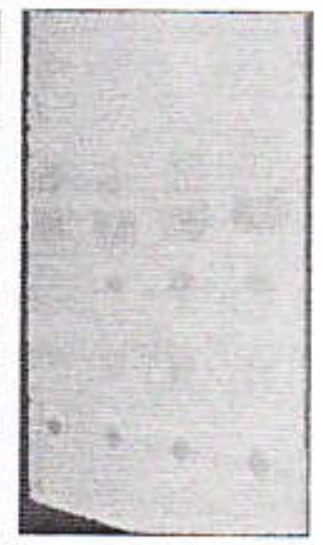

$365 \mathrm{~nm}$

Gambar 3. Hasil Analisa Ekstraksi Methanol Bawang Tiwai dengan KLC/TLC 


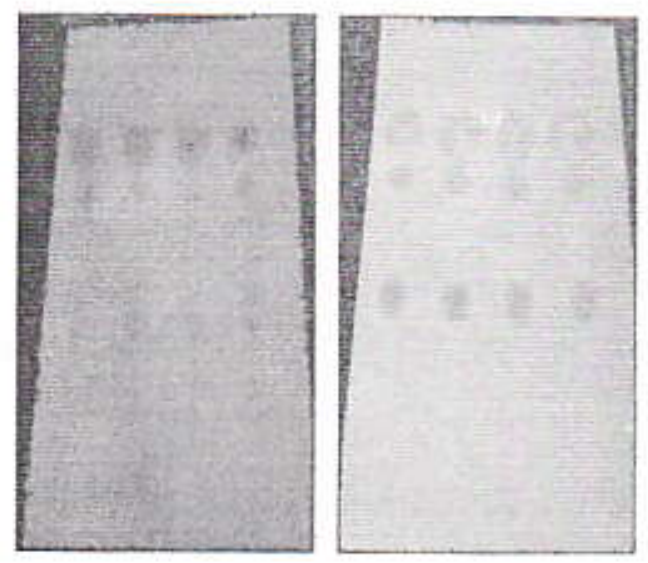

Gambar 4. Hasil Analisa Ekstraksi Air Bawang Tiwai dengan KLC/TLC

\section{Hasil Analisa Fitokimia}

Berdasarkan hasil analisa fitokimia Ekstrak bawang tiwai dengan menggunakan methanol dan air berturut-turut mengandung flavonoid, alkoloide-keton, asam karboksilat, tanin. Sedangkan ekstraksi bawang tiwai dengan menggunakan air mengandung glikosida tetapi dengan menggunakan methanol tidak terdeteksi.

Berdasarkan data analisa fitokimia ekstrak bawang tiwai dengan methanol dan air panas mengandung senyawa flavonoid, glikosida, aldehid - keton, asam karboksilat dan tanin. Hal ini diperjelas oleh Sukrasno, dkk (2006) bahwa bawang tiwai mengandung flavonoid, alkaloid, tanin dan triterpenoid atau steroid.

Dari senyawa kimia yang terdapat pada bawang tiwai mempunyai beberapa manfaat bagi kelangsungan hidup manusia pada bidang kesehatan antara lain: flavanoid terutama berupa senyawa yang larut dalam air, dapat diekstraksi dengan etanol $70 \%$ dan tetap ada lapisan air setelah ekstraksi ini dikocok dengan eter minyak bumi. Flavanoid mengandung sistem aromatika yang terkonjugasi, umumnya terdapat dalam tumbuhan, terikat pada gula sebagai glikosida dan aglikon flavanoid. Flavanoid terdapat dalam tumbuhan sebagai campuran yang berbeda kelas (Harbome, 1987).

Efek biologis yang ditunjukkan flavonoid antara lain anti alergi, anti peradangan, dan aktivitas anti kanker serta bertindak sebagai anti oksidan yang kuat (Anonim, 2005). Lanjut Buhler dan Miranda (2005) flavonoid merupakan komponen yang dapat ditemukan di dalam buahbuahan, sayur-mayur dan hidangan tertentu yang mempunyai bermacam kandungan biokimia dan efek antioksidan. Antioksidan adalah suatu campuran yang melindungi sel dari kerusakan akibat oksigen reaktif atau radikal bebas. Ketidakseimbangan antara antioksidan dan jenis oksigen reaktif dapat menyebabkan oksidatif tertekan yang mendorong kearah kerusakan sel seperti kanker, peradangan dan penyakit neurodegeneratif(Parkinson dan Alzheimer).

Menurut Nishino, kuersitin (suatu flavonol) dapat menghambat pertumbuhan tumor kulit, sehingga senyawa ini dapat digunakan sebagai pencegahan kimiawi dari pertumbuhan tumor, walaupun flavonoid ini bersifat mutagenic. Disamping tiu, Anonim (1984) telah melaporkan pula formulasi - formulasi antitumor yang mengandung flavonoid dan isoflavonoid, misalnya gnistein (suatu isoflavonoid).

Di Jerman misalnya, ekstrak dari buah Crataegus oxycantha yang mengandung flavonoid telah digunakan untuk mengobati penyakit jantung, sebagai vasodilator yang lunak (Crataegutt, "Schwabe"; Cratelyn "Madaus"). Begitu pula akstrak flavonoid ginkgetin dari daun Ginko biloba 
telah digunakan untuk memperbaiki peredaran darah di otak, varises, dan hemorrhoid dengan nama dengan Tebonim "Schwabe". Metabolit sekunder sebagai "chemical messenger"

Pada analisa bawang tiwai mengandung glikosida, dimana glikosida mudah terhidrolisis oleh larutan asam berair menjadi gula-gula bebas tetapi mereka sangat stabil terhadap alkali.

Menurut Robinson Trevor (1995) bahwa Glikosida jantung ditemukan dalam beberapa keluarga tumbuhan yang sama sekali tidak berkaitan satu sama lain seperti Apocynaceae, Liliaceae, Moraceae, dan Ranunculaceae. Tumbuhan yang mengandung senyawa ini telah digunakan sejak zaman prasejarah sebagai racun dan siksaan. Glikosida ini mempunyai efek kardiotonik khas dan tapak kerja molekulnya adalah ATPase yang terikat pada membran yang mengatur angkutan kation. Keberadaan senyawa ini dalam tumbuhan mungkin memberi perlindungan kepada tumbuhan dari gangguan beberapa serangga tertentu. Dijelaskan Riawan S (1990) bahwa glikosida digunakan sebagai antipiretik dan obat terhadap reumatik, selain itu juga untuk keaktifan atas jantung dan untuk penyakit jantung tertentu. Dijelaskan oleh Riawan S (1990) turunan dari glikosida dalam ilmu kedokteran digunakan untuk salep dan sebagainya sedangkan untuk farmasi digunakan untuk kosmetik misalnya krim dan sebagainya.

Terdapat aldehid-keton pada bawang tiwai disebabkan adanya gugus karbonil diikat oleh satu gugus alkil/aril R-COH (Respati, 1986). Dijelaskan oleh Riawan S (1990) bahwa turunan dari aldehide-keton, aldehid aromatik mempunyai bau yang khas, maka ada yang dipergunakan dalam wangi - wangian, makanan dan hasil fermentasi. Selain senyawa kimia yang telah disebutkan diatas bahwa bawang tiwai mengandung asam karboksilat dan tanin. Asam karboksilat menurut Respati (1986) Golongan senyawa ini antara lain asam format, asam acetat, asam laurat, asam oleat, asam benzoat, asam fenil acetat, dan asam fialat. Golongan asam ini larut dalam solvent organik antara laian eter, alkohol, benzena dan larut dengan air panas. Asam benzoat merupakan kristal, garam Na dari asam benzoat dipergunakan untuk pengawetan makanan dan sifat asamnya lebih kuat daripada asam acetat.

Sedangkan tanin menurut Robinson Trevor (1995) adalah merupakan sejenis kandungan tumbuhan yang bersifat fenol mempunyai rasa sepat dan mempunyai kemampuan menyamak kulit, tetapi secara kimia tanin tumbuhan dibagi dua golongan yaitu tanin kondensasi atau tanin katekin lebih penting dari segi penyamakan. Sedangkan tanin terhidrolisasikan mengandung ikatan ester yang dapat terhidrolisis jika dididihkan dalam asam klorida encer.

Tanin terhidrolisa biasanya berupa senyawa amorf, higroskopis, berwarna coklat kuning yang larut dalam air (terutama air panas) membentuk larutan koloid bukan lartutan sebenarnya. Makin murni tanin, makin kurang kelarutannya dalam air dan makin mudah diperoleh dalam bentuk kristal. Tanin ini larut pula, setidak-tidaknya sampai batas tertentu, dalam pelarut organik yang polar, tetapi tak larut dalam pelarut organik nonpolar seperti benzene dan kloroform. Larutan tanin dalam air dapat diendapkan dengan penambahan asam mineral atau garam. Kemampuan tanin untuk bereaksi dengan protein dan mengendapkannya menimbulkan masalah pada penyiapan enzim atau protein lain dari beberapa tumbuhan. Antaraksi tanin dengan protein bersifat khas dan bergantung pada struktur tanin. Kadar tanin yang tinggi mungkin mempunyai arti pertahanan bagi tumbuhan, membantu mengusir hewan pemangsa tumbuhan. Selain itu, kadar tanin yang tinggi dianggap mempunyai mempunyai pengaruh yang merugikan terhadap nilai tumbuhan makanan ternak. Senyawa aktif dalam tumbuhan obat tertentu mungkin tanin. Beberapa tanin terbukti mempunyai aktifitas antioksidan, menghambat pertumbuhan tumor, dan menghambat enzim seperti "reverse" transkriptase dan DNA topisomerase. 
Bawang tiwai mengandung fenol, menurut Robinson Trevor (1995) mengatakan bahwa kelarutan dalam air bertambah jika gugus hidroksil makin banyak, tetapi kelarutan dalam pelarut organik yang polar umumnya tinggi. Fenol yang kelarutannya kecil, mudah larut dalam natrium hidroksida encer dalam air. Beberapa tumbuhan tampaknya menjadi tahan serangan fungus karena senyawa fenol yang dikandungnya, tetapi ketahanannya itu mungkin bersifat khas, hanya terhadap jenis fungus tertentu. Dijelaskan Riawan S (1990) bahwa fenol digunakan sebagai antiseptikum (Mungkin karena mempunyai sifat mengkoagulasi protein). Selain itu Koefisien fenol merupakan perbandingan konsentrasi fenol dengan konsentrasi zat untuk mematikan suatu macam bakteri dalam waktu yang sama.

Hasil analisa bawang tiwai mengandung beberapa senyawa kimia antara lain karbohidrat $59,03 \%$ dan protein $14,46 \%$. Kandungan 2 (dua) senyawa kimia ini cukup besar sehingga dapat dimanfaatkan untuk keperluan-keperluan bahan baku dalam kehidupan sehari-hari. Dijelaskan oleh Girindra (1990) bahwa bersama-sama dengan lemak dan protein. karbohidrat memegang peranan dasar bagi kehidupan di bumi ini. Bukan saja sebagai sumber energi utama bagi mahluk hidup, tetapi juga sebagai senyawa yang menyimpan energi kimia. Pada hewan atau manusia energi disimpan sebagai glikogen dan pada tanaman sebagai pati. Disamping kedua senyawa tersebut ada pula karbohidrat pembentuk struktur, misalnya selulosa yang berperanan sebagai komponen utama dinding sel tumbuhan dan peptidoglikan yang terdapat di dinding sel bakteri. Sedangkan protein pada bawang tiwai mempunyai persen kandungan senyawa kimia urutan kedua. Menurut Sudarmadji, dkk., (1989) mengatakan bahwa protein alamiah mula-mula dibentuk dari unit-unit asam amino yang dirakit sama sekali baru oleh organisme outrothoph dari unsurunsur organik $\mathrm{H}, \mathrm{O}, \mathrm{N}$, dan $\mathrm{S}$ yang ada dalam tanah atau udara. Organisme heterotroph hanya dapat menggunakan protein jadi yang sudah dirakit oleh organisme outrotroph tadi. Oleh sebab itu protein yang ada dalam bahan makanan sangat penting bahkan vital bagi organisme heterotroph seperti manusia. Protein-protein tersebut berguna untuk penyusunan senyawa-senyawa biomolekul yang berperan penting dalam proses biokimiawi, untuk mengganti sel-sel jaringan yang rusak

Kelarutan senyawa kimia yang terdapat pada bawang tiwai bertutur-turut dengan air panas $91,93 \%$ disusul dengan ethanol $89,91 \%$. Kelarutan senyawa kimia ini diduga bahwa ikatan-ikatan kimia yang terdapat pada bawang tiwai mudah lepas sehingga kadar sari terlarut yang terbentuk cukup besar. Berdasarkan hasil ekstrak bawang tiwai dengan methanol dan air panas berturutturut memiliki ciri-ciri padatan coklat, non kristalin dan padatan coklat marun serta non kristalen. Sedangkan menurut Sukrasno dkk (2006) mengatakan bahwa ekstrak dengan pelarut air melalui perebusan tiga kali masih menghasilkan ekstrak yang berwarna merah, yang menunjukkan masih banyaknya senyawa tertahan di dalam residu bawang tiwai. Berdasarkan data kromatografi menunjukkan bahwa warna merah ini merupakan kelompok senyawa polar yang mudah larut dalam pelarut polar seperti ethanol, methanol, air atau campurannya.

\section{KESIMPULAN DAN SAR.AN}

Bawang Tiwai mengandung se ny a wa kimia Flafonoid, Aldehid keton, Asam karboksilat, Glikosida, Tanin, Fenol, Karbohidrat, dan Protein.

Bawang Tiwai dapat dijadikan b a h a n baku industri obat dan bahan tambahan pangan. Perlu dilakukan penelitian lanjutan untuk bahan tambahan makanan. 


\section{DAFTAR PUSTAKA}

Anonim, 2004. Indonesia Mampukah Menjadi Negara Jamu Plus Sehat (Mitra Maju Hidup Sehat) No. 6/Nol.2/2004. Jakarta

Anonim,2005. Flavonoid. http://www.en.wikipedia.org/wiki/Flavonoid. 10/01/2006

Buhler. D.R., Miranda. C, 2005. Antiozidant Activities of Flavonoids. Department Of Environmental and Molecular Toxicology. Oregon State University. http://lpi.oregonstate.eu/fw00/flavonoid.html 10/02/2006

Girindra_A. 1990. Biokimia I. Penerbit PT Gramedia. Jakarta.

Harborne, J.B. 1987. Metode Fitokimia (Terjemahan). Edisike-2. Penerbit ITB. Bandung.

Respati. 1986. Pengantar Kimia Organik Jilid I. Aksara Baru. Yogyakarta

Riawan S. 1990. Kimia Organik. Bina rupa Aksara. Grogol

Robinson. T. 1995. Kandungan Organik Tumbuhan Tingkat Tinggi. Penerbit ITB. Bandung

Sudarmadji, S., B. Haryono., Suhardi. 1989. Analisa Bahan Makanan dan Pertanian. Penerbit Liberti Yogya. Yogyakarta

Sukrasno, Urnemi, Sadaruddin, 2006. Penelitian Obat-obatan Tradisional Mikropropagasi dan Pengembangan Bawang Tiwai/Bawang Sabrang (Eleutherine americana L.) sebagai obat Herbal. ITB. Bandung 